\title{
Winter dispersal of rockhopper penguins Eudyptes chrysocome from the Falkland Islands and its implications for conservation
}

\author{
Klemens Pütz ${ }^{1, *}$, Rebecca J. Ingham ${ }^{2}$, Jeremy G. Smith ${ }^{2}$, Bernhard H. Lüthi ${ }^{3}$ \\ ${ }^{1}$ Antarctic Research Trust, PO Box 685, and ${ }^{2}$ Falklands Conservation, PO Box 26, Stanley, Falkland Islands, South Atlantic \\ ${ }^{3}$ Antarctic Research Trust (Switzerland), General-Guisanstr. 5, 8127 Forch, Switzerland
}

\begin{abstract}
In 3 successive years (1998 to 2000), the winter migration of rockhopper penguins Eudyptes chrysocome from 3 separate breeding colonies on the Falkland Islands was monitored using satellite transmitters. After their moult, 34 penguins were followed for a mean transmission period of $81 \pm 21 \mathrm{~d}$. While there were substantial spatial and temporal variations in migration patterns, we identified several foraging areas where food availability is presumably higher than elsewhere. Coastal areas of the Falkland Islands and South America appeared to provide a sufficient food supply, and many penguins commuted between these 2 areas, which are about $600 \mathrm{~km}$ apart. Rockhopper penguins from northern breeding colonies also used areas along the slope of the Patagonian Shelf up to $39^{\circ} \mathrm{S}$, about $1400 \mathrm{~km}$ northwards. By contrast, only a few birds from the southern breeding colony migrated to the Burdwood Bank, which is situated about $250 \mathrm{~km}$ to the south of the Falkland Islands, and adjacent oceanic waters. None of the penguins in this study left the maritime zone of the Falkland Islands in an easterly direction to forage in oceanic waters. The mean distances covered per day by individual birds varied greatly, depending on the phase of the foraging trip. The overall mean travelling speed was $26 \mathrm{~km} \mathrm{~d}^{-1}$ (range: 13 to $45 \mathrm{~km} \mathrm{~d}^{-1}$ ). Inter-annual variation was evident both in the use of different foraging areas, and also in the time at which the winter migration began. In 1998 and 2000, penguins from Seal Bay and Sea Lion Island left their breeding colony within 1 wk after being equipped with transmitters and did not return, whereas in 1999 most penguins made short foraging trips and returned repeatedly to their colonies for periods of up to $100 \mathrm{~d}$. Potential threats to the rockhopper penguins during their winter migration, resulting from human activities such as fishing and oil pollution within the Falkland Islands maritime zone and the Argentine Exclusive Economic Zone, are discussed.
\end{abstract}

KEY WORDS: Rockhopper penguins - Satellite telemetry - Winter migration - Foraging areas · Southwest Atlantic

\section{INTRODUCTION}

Rockhopper penguins Eudyptes chrysocome breed on sub-Antarctic and temperate islands throughout the Southern Ocean (Williams 1995). In the Falkland Islands, the rockhopper penguin population was estimated to

*Present address: Gottfried-Keller-Str. 13, 53757 St. Augustin, Germany. E-mail: k.putz@surfeu.de comprise about 3 million breeding pairs in the early 1930s (Bennett 1933). However, the population has since declined to about 275000 breeding pairs (Clausen 2001). A similar trend has been observed on Campbell Island in the South Pacific, where breeding numbers of rockhopper penguins have fallen from 1.6 million breeding pairs in the early 1940s to fewer than 100000 (Moors 1986). Declines in the rockhopper penguin population have also been noted on the Auckland Islands (Cooper 1992), Marion Island (Cooper et al. 1997), Antipodes Islands 
(Ellis et al. 1998) and Amsterdam Island (Guinard et al. 1998). By comparison, the population of the recently discovered colony on Staten Island seems to have remained stable, as there are no signs of ground erosion indicating a larger colony in former times (Schiavini 2000). Nevertheless, the widespread reduction in population has resulted in the classification of rockhopper penguins as a globally threatened species according to IUCN criteria (BirdLife International 2000).

The reasons for the significant population declines are largely unknown. Starvation prior to moult was thought to be responsible for a mass mortality of rockhopper penguins in the Falkland Islands during the 1985/86 breeding season (Keymer et al. 2001). The decline on Campbell Island has been attributed to a rise in sea temperature, which may have resulted in reduced food availability (Cunningham \& Moors 1994). On the other hand, it has been assumed that a drop in sea surface temperature caused a population decline of rockhopper penguins on Amsterdam Island, although populations on Saint Paul Island, $80 \mathrm{~km}$ to the south of Amsterdam Island, increased over the same period (Guinard et al. 1998). Given the wide breeding range of rockhopper penguins, from sub-Antarctic to subtropical waters, it seems unlikely that the cited changes in sea surface temperature were solely responsible for the population declines. Other factors must contribute to the global decrease in breeding pair numbers, such as possible changes in the oceanographic features of the Southern Ocean (e.g. Croxall 1992, Fraser et al. 1992). Furthermore, human activities such as commercial fishing (e.g. Montevecchi 2002) and pollution (e.g. Burger \& Gochfeld 2002) may contribute locally to the declines.

Human activities in Falkland Island waters have increased greatly over the past 2 decades. Fishing has expanded rapidly since the mid-1970s, eventually threatening fish and squid stocks (Patterson 1987). As a result, maritime conservation zones have been established around the Falkland Islands and the number of fishing vessels within these areas has been strictly regulated (Barton 2002). Exploration for hydrocarbon deposits began north of the Falkland Islands in 1998, and the results of this drilling are fuelling growing interest in further oil exploration and production in Falkland Islands waters (Richards 2002). Ship-based tourism has also grown and more than 30000 tourists now visit the islands each season (Ingham \& Summers 2002). All these activities have the potential to threaten penguin populations breeding in the Falkland Islands, adding to the existing threats.

The breeding success and diet of rockhopper penguins have been monitored on the Falkland Islands for the last 15 yr. The data collected so far have failed to highlight any detrimental influences during the breed- ing season (Pütz et al. 2001). Rockhopper penguins are probably exposed to potential threats during their winter migration, which can last up to $6 \mathrm{mo}$, and it is essential to gain insight into their utilisation of the marine habitat during winter. The aim of this study was to monitor the winter dispersal of rockhopper penguins from the Falkland Islands using satellite transmitters. To allow for spatial and inter-annual variation, transmitters were attached to penguins from colonies distributed over the entire archipelago, over 3 successive years. The data may assist in identifying areas that need special attention in order to protect Falkland Islands rockhopper penguins.

\section{MATERIALS AND METHODS}

Field work was conducted between 1998 and 2000 at Seal Bay to the northeast of the Falkland Islands $\left(51^{\circ} 37^{\prime} \mathrm{S}, 58^{\circ} 02^{\prime} \mathrm{W}\right)$, in 1999 and 2000 on Sea Lion Island to the south of the Falkland Islands $\left(52^{\circ} 45^{\prime} \mathrm{S}\right.$, $\left.59^{\circ} 12^{\prime} \mathrm{W}\right)$, and in 2000 on Saunders Island to the northwest of the Falkland Islands $\left(51^{\circ} 31^{\prime} \mathrm{S}, 60^{\circ} 23^{\prime} \mathrm{W}\right)$. The breeding sites chosen were assumed to be representative of the most important concentrations of rockhopper penguins in the Falkland Islands (see Bingham 1998). A total of 34 rockhopper penguins were equipped with satellite transmitters at their breeding colonies after completion of the moult. At Seal Bay, satellite transmitters were attached to penguins on 24 March 1998 $(\mathrm{n}=5), 19$ March $1999(\mathrm{n}=6)$ and 4 April $2000(\mathrm{n}=6)$. On Sea Lion Island, penguins were equipped with satellite transmitters on 26 March $1999(\mathrm{n}=6)$ and on 27 March $2000(n=6)$. Satellite transmitters were attached to birds on Saunders Island on 30 March 2000 (n = 5).

Rockhopper penguins were caught at their ankle joint using a $1.5 \mathrm{~m}$ length of wire bent into a hook at one end. After covering the head and immobilising the penguin to minimise disturbance, the birds were weighed and bill dimensions measured to determine their gender (following the methodology established by Hull 1996, K. Pütz unpubl. data). The satellite transmitters were attached on the mid-line of the back as far distally as possible without impairing the preen gland, using black tape (Tesa) and 2-component neoprene glue (Deutsche Schlauchbootfabrik) according to Wilson et al. (1997). The devices were then covered with a layer of quick epoxy (Loctite ${ }^{\circledR}$ 3430) to prevent the birds from removing the tape with their beaks. Equipping the penguins took place in the back of a heated vehicle to minimise the hardening times of the glues. The whole process took less than 20 min per bird.

Two types of satellite transmitters were used in this study. In 1998 and 1999, ST-10 satellite transmitters (manufactured by Telonics and modified by Sirtrack) 
were attached to the penguins, whereas in 2000 KiwiSat 101 satellite transmitters (Sirtrack) were used. All devices were embedded in epoxy resin and hydrodynamically shaped following the recommendations by Bannasch et al. (1994). From 1999 onwards, the base of all the devices was moulded into a concave shape to better match the anatomy of the penguin's back. The satellite transmitters were powered by 2 AA lithium cells; they weighed approximately $100 \mathrm{~g}$, equivalent to less than $5 \%$ of the mean penguin body mass (Table 1). Maximum dimensions of the ST-10 transmitters were $130 \times 40 \times 20 \mathrm{~mm}$, whereas the KiwiSat 101

Table 1. Eudyptes chrysocome. Data from satellite transmitters deployed on Falkland Island rockhopper penguins. Calculation of the minimum distance covered per day is based on the total transmitting time minus residence time

\begin{tabular}{|c|c|c|c|c|c|c|c|c|c|}
\hline \multicolumn{2}{|c|}{$\begin{array}{l}\text { Penguin } \\
\text { name }\end{array}$} & \multirow[t]{2}{*}{$\begin{array}{l}\text { Body } \\
\text { mass } \\
(\mathrm{kg})\end{array}$} & \multirow[t]{2}{*}{ Sex } & \multirow[t]{2}{*}{$\begin{array}{l}\text { No. of locations } \\
\text { per hour of } \\
\text { transmission }\end{array}$} & \multirow[t]{2}{*}{$\begin{array}{l}\text { Residence time } \\
\text { in colony } \\
\text { (d) }\end{array}$} & \multirow[t]{2}{*}{$\begin{array}{l}\text { Transmission } \\
\text { period } \\
\text { (d) }\end{array}$} & \multirow[t]{2}{*}{$\begin{array}{c}\text { Maximum distance } \\
\text { to colony } \\
(\mathrm{km})\end{array}$} & \multicolumn{2}{|c|}{$\begin{array}{c}\text { Minimum distance } \\
\text { covered } \\
(\mathrm{km}) \quad\left(\mathrm{km} \mathrm{d}^{-1}\right)\end{array}$} \\
\hline \multicolumn{4}{|c|}{ Seal Bay } & & & & & & \\
\hline \multirow[t]{6}{*}{1998} & Hugo & 2.6 & M & 0.36 & 3 & 60 & 572 & 1095 & 19 \\
\hline & Jule & 2.0 & $\mathrm{~F}$ & 0.48 & 3 & 69 & 690 & 1488 & 23 \\
\hline & Marianne & 2.5 & $\mathrm{~F}$ & 0.63 & 6 & 111 & 158 & 1333 & 13 \\
\hline & Scouty & 3.0 & M & 0.35 & 6 & 54 & 685 & 1175 & 24 \\
\hline & Sir Stanley & 2.9 & M & 0.43 & 3 & 73 & 659 & 2119 & 30 \\
\hline & Means \pm SD & & & $0.45 \pm 0.11$ & $4.2 \pm 1.6$ & $73.4 \pm 22.3$ & $553 \pm 226$ & $1442 \pm 407$ & 21 \\
\hline \multirow{7}{*}{1999} & Paradise & 2.3 & M & 0.48 & 2 & 129 & 654 & 4526 & 36 \\
\hline & Reinhold & 2.9 & M & 0.60 & 32 & 105 & 300 & 1727 & 24 \\
\hline & Romana & 2.0 & $\mathrm{~F}$ & 0.43 & 52 & 97 & 1447 & 2019 & 45 \\
\hline & $\operatorname{Sarah}^{\mathrm{a}}$ & 1.8 & $\mathrm{~F}$ & 0.15 & 45 & 100 & 1406 & 1864 & 34 \\
\hline & Sokrates & 2.3 & M & 0.55 & 102 & 111 & 46 & 119 & 13 \\
\hline & Vontobel $^{\mathrm{a}}$ & 2.6 & M & 0.08 & 1 & 94 & 298 & 1740 & 19 \\
\hline & Means $\pm \mathrm{SD}$ & & & $0.38 \pm 0.22$ & $39.0 \pm 37.5$ & $106.0 \pm 12.8$ & $692 \pm 601$ & $1999 \pm 1420$ & 30 \\
\hline \multirow[t]{7}{*}{2000} & Chippys & 2.1 & $\mathrm{~F}$ & 0.30 & 3 & 83 & 703 & 1985 & 25 \\
\hline & Friedli & 2.2 & M & 0.35 & 3 & 89 & 194 & 1348 & 16 \\
\hline & Ocean Speedy & $y \quad 2.4$ & $\mathrm{~F}$ & 0.20 & 4 & 60 & 646 & 964 & 17 \\
\hline & Otto & 2.3 & M & 0.28 & 2 & 84 & 985 & 1913 & 23 \\
\hline & Susanne & 2.2 & $\mathrm{~F}$ & 0.23 & 2 & 56 & 673 & 1355 & 25 \\
\hline & Victory & 2.4 & $\mathrm{M}$ & 0.32 & 7 & 81 & 1217 & 2066 & 28 \\
\hline & Means $\pm \mathrm{SD}$ & & & $0.28 \pm 0.06$ & $3.5 \pm 1.9$ & $75.5 \pm 13.9$ & $736 \pm 346$ & $1605 \pm 445$ & 22 \\
\hline \multicolumn{10}{|c|}{ Sea Lion Island } \\
\hline \multirow[t]{7}{*}{1999} & Aika & 1.8 & $\mathrm{~F}$ & 0.42 & 27 & 86 & 501 & 2419 & 41 \\
\hline & Balou & 2.7 & M & 0.42 & 21 & 86 & 546 & 2378 & 37 \\
\hline & Hope & 1.7 & $\mathrm{~F}$ & 0.63 & 25 & 107 & 414 & 2947 & 36 \\
\hline & Karajan & 2.1 & M & 0.32 & 39 & 84 & 699 & 1186 & 26 \\
\hline & Leonardo & 1.8 & M & 0.20 & 46 & 86 & 585 & 1348 & 34 \\
\hline & Summer & 2.1 & M & 0.48 & 27 & 73 & 658 & 1738 & 38 \\
\hline & Means \pm SD & & & $0.41 \pm 0.15$ & $30.8 \pm 9.6$ & $87.0 \pm 11.0$ & $567 \pm 104$ & $2003 \pm 689$ & 36 \\
\hline \multirow[t]{7}{*}{2000} & Benno & 2.2 & M & 0.32 & 6 & 67 & 304 & 1083 & 18 \\
\hline & Max & 2.1 & M & 0.33 & 7 & 46 & 65 & 573 & 15 \\
\hline & Moritz & 2.3 & M & 0.02 & 2 & 83 & & & \\
\hline & Petra & 1.7 & $\mathrm{~F}$ & 0.53 & 2 & 64 & 294 & 974 & 16 \\
\hline & Stella & 2.0 & $\mathrm{~F}$ & 0.42 & 7 & 90 & 284 & 1588 & 19 \\
\hline & Vreni & 2.2 & $\mathrm{~F}$ & 0.48 & 6 & 23 & 232 & 401 & 24 \\
\hline & Means \pm SD & & & $0.35 \pm 0.18$ & $5.0 \pm 2.4$ & $62.2 \pm 24.6$ & $236 \pm 99$ & $924 \pm 465$ & 16 \\
\hline \multicolumn{10}{|c|}{ Saunders Island } \\
\hline \multirow[t]{6}{*}{2000} & Benji & 2.1 & M & 0.15 & 26 & 86 & 563 & 1530 & 26 \\
\hline & Cyrus & 2.0 & M & 0.42 & 10 & 69 & 883 & 1604 & 27 \\
\hline & Inca & 2.1 & $\mathrm{~F}$ & 0.38 & 29 & 87 & 844 & 1765 & 30 \\
\hline & Мара & 2.0 & M & 0.43 & 7 & 87 & 645 & 1900 & 24 \\
\hline & Millie & 2.4 & $\mathrm{~F}$ & 0.38 & 6 & 73 & 1363 & 2063 & 31 \\
\hline & Means $\pm \mathrm{SD}$ & & & $0.35 \pm 0.12$ & $15.6 \pm 11.0$ & $80.4 \pm 8.7$ & $860 \pm 312$ & $1772 \pm 217$ & 27 \\
\hline \multicolumn{2}{|l|}{ Total } & $2.2 \pm 0.3$ & & $0.37 \pm 0.15$ & $16.7 \pm 21.2$ & $81.0 \pm 20.8$ & $613 \pm 365$ & $1646 \pm 782$ & 26 \\
\hline \multicolumn{2}{|c|}{ Males } & $2.3 \pm 0.3$ & & & & & & & \\
\hline \multicolumn{2}{|c|}{ Females } & $2.1 \pm 0.3$ & & & & & & & \\
\hline
\end{tabular}


used in 2000 was slightly slimmer with $130 \times 35 \times$ $20 \mathrm{~mm}$. The flexible antenna at the rear of the device was $170 \mathrm{~mm}$ long and $3 \mathrm{~mm}$ in diameter.

To reduce the energy requirements of the satellite transmitters, devices were programmed to transmit at a duty cycle with a repetition period of $60 \mathrm{~s}$, and a submersion switch prevented transmission while underwater. Duty cycles were 8:64 h on:off in 1998, 6:42 and 6:18 h in 1999 for penguins from Seal Bay and Sea Lion Island, respectively, and 6:18 h on:off for all penguins in 2000. Transmitters were usually switched on at night (but see Table 1), as this time offered the best compromise between low penguin activity and high frequency of satellite overpasses (local time $=\mathrm{GMT}+3 \mathrm{~h}$ ). Positional data obtained from Argos (CLS) were classified according to the quality of the positional fix, with location Classes 0, 1, 2 and 3 representing accuracies of $>1 \mathrm{~km},<1 \mathrm{~km},<350 \mathrm{~m}$ and $<150 \mathrm{~m}$, respectively (Argos 1996). However, the margin of error may be greater, because of the movement of the penguins between satellite uplinks (cf. Kerry et al. 1995). Positions were processed using the EXCEL program (Microsoft). The most accurate position obtained in each duty cycle for each penguin ( $\geq 76 \%$ of locations in Class 1 ) was transferred to MAPINFO Professional 5.0 (MapInfo). Calculation of the maximum distance to the colony and distance between two consecutive fixes was carried out using HOWFAR (Jensen Software Systems).

The submersion switch of the ST-10 transmitters continuously recorded and subsequently transmitted in 16-bit format the time spent underwater by the penguins. The submersion switch could record a maximum of 65535 units ( 1 unit $=1.024 \mathrm{~s}$ ), or $18.6 \mathrm{~h}$ overall. Therefore, reliable values for the time spent underwater were obtained only from devices programmed to transmit with a duty cycle of $6: 18 \mathrm{~h}$ (essentially birds from Sea Lion Island in 1999). Calculation of travelling speed was based on the relationship between time spent underwater and the distance travelled between 2 consecutive locations. Values for travelling speed are minimum values and differ from the actual swim speed of the birds since horizontal and vertical deviations from a straight line course between 2 locations, and drift with water currents, are neglected. All values given are mean \pm standard deviation (SD) unless otherwise indicated in the text. Statistical tests were performed using PRISM 2.01 (GraphPad Software).

\section{RESULTS}

The winter migration of rockhopper penguins from the Falkland Islands was monitored for a mean tracking duration of $81 \pm 21 \mathrm{~d}$ (range 23 to $129 \mathrm{~d}$ ). Data on the foraging trips are summarised in Table 1 . Six rock- hopper penguins were re-sighted in their colonies in the following breeding season, apparently following the usual breeding routine. They were identified by the absence of the outer part of the feathers in an area corresponding to the base of the devices.

\section{Seal Bay}

In 1998, all 5 rockhopper penguins from Seal Bay left their colony within $1 \mathrm{wk}$ after being equipped with a satellite transmitter. Thereafter, their migration was monitored for a mean duration of $73 \pm 22 \mathrm{~d}$ (Table 1). The area utilised by these birds ranged from the Falkland Islands northwestwards to an area off Puerto Deseado, Argentina, about $600 \mathrm{~km}$ from their colony (Fig. 1). They remained in this area for varying periods,

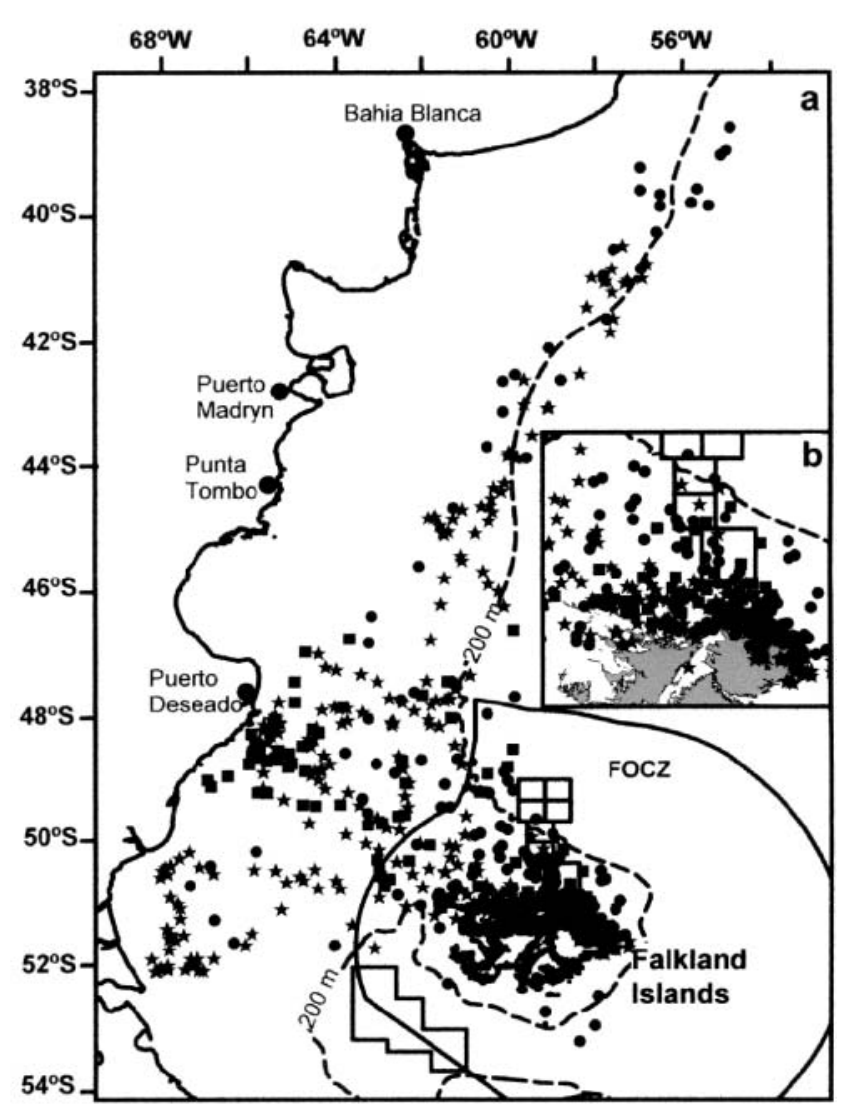

Fig. 1. Eudyptes chrysocome. Positions of rockhopper penguins from Seal Bay during winters 1998 to $2000(\boldsymbol{\square}=1998, \bullet=1999$ and $\star=2000$ ). Data for all 3 study years were combined, due to the lack of significant inter-annual differences in foraging parameters (see Table 2). The squares to the north and to the southwest of the Falkland Islands are prospective areas for oil exploration and exploitation. The solid line indicates the border of the Falklands Outer Conservation Zone (FOCZ), and the dotted line is the $200 \mathrm{~m}$ water depth contour. (a) Overview, (b) coastal detail 
and transmissions from all penguins ceased before they returned to the Falkland Islands. One of the penguins remained for the whole transmission period within coastal waters of the Falkland Islands, never travelling further than $160 \mathrm{~km}$ from the coast (Table 1).

In 1999 the migrations of the rockhopper penguins tracked at Seal Bay were monitored for a mean duration of $106 \pm 13 \mathrm{~d}$. During the initial tracking period, 4 of the 6 penguins repeatedly returned to the breeding colony after making brief foraging trips of up to a few days, whereas the 2 other penguins left the colony immediately after being fitted with a transmitter (Table 1). As all of the positions obtained from the penguins during the initial period, during which they returned frequently to the colony, were either at the colony or close to shore, only positions obtained after this period for each individual were plotted (Fig. 1). Of the 6 penguins, 3 remained within the Falklands Outer Conservation Zone (FOCZ) throughout the study period, and 3 left the FOCZ. Of the latter, 1 penguin left the FOCZ repeatedly on westerly courses and the other 2 migrated north until transmission ceased north of $40^{\circ} \mathrm{S}$. These differences in the foraging behaviour are reflected in the calculated maximum distances to the colony and minimum distances covered (Table 1).
During the austral winter 2000, contact with rockhopper penguins from the colony at Seal Bay was maintained for a mean period of $76 \pm 14 \mathrm{~d}$ (Table 1). As had been the case in 1998, most penguins left the moulting site within $1 \mathrm{wk}$ after being equipped with a transmitter (Fig. 1). Of the 6 penguins tracked, 2 individuals again used the area off Puerto Deseado, Argentina, 1 individual also foraged further south between $50^{\circ}$ and $52^{\circ} \mathrm{S}, 2$ individuals migrated north until transmission ceased at about $39^{\circ} \mathrm{S}$, and 1 penguin remained within coastal waters of the Falkland Islands during the entire transmission period of $89 \mathrm{~d}$, never travelling further than $200 \mathrm{~km}$ from the coast.

\section{Sea Lion Island}

Rockhopper penguins from Sea Lion Island were tracked for a mean period of $87 \pm 11 \mathrm{~d}$ during the austral winter 1999 (Fig. 2). After finishing their moult, the penguins undertook day trips for a mean duration of $31 \pm 10 \mathrm{~d}$, during which time they returned frequently to their colony, thus displaying the same behaviour as their conspecifics from Seal Bay in that year (Table 1). After this period, 5 of the 6 penguins left the FOCZ at least once in a westerly direction and foraged close to the South American coast at different latitudes and for various periods. The remaining penguin travelled $250 \mathrm{~km}$ southwards to Burdwood Bank, an isolated extension of the Patagonian Shelf with a water depth of less than $200 \mathrm{~m}$, and adjacent areas to the northeast.

The submersion switch in the satellite transmitters allowed calculation of the time spent underwater between consecutive locations in penguins from Sea Lion Island, because these devices were programmed to transmit with a duty cycle of $6: 18 \mathrm{~h}$ on-off. The frequency distribution of the time spent underwater is skewed to the right (Fig. 3). The mean time spent underwater was $9.4 \pm 2.5 \mathrm{~h}$ $\mathrm{d}^{-1}$ (range 4.3 to 17.9 , median 8.9). More than $25 \%$ of all periods underwater ranged between 8 and $9 \mathrm{~h}$, and about $75 \%$ of all periods were within the range of 6 to $10 \mathrm{~h}$. The mean travelling speed for these penguins, based on the time spent underwater and the distance covered between 2 consecutive locations, was $1.1 \pm 0.1 \mathrm{~m} \mathrm{~s}^{-1}$ (range 1.0 to 1.3 ).

In 2000, rockhopper penguins from the colony at Sea Lion Island departed
Fig. 2. Eudyptes chrysocome. Migration routes of rockhopper penguins from

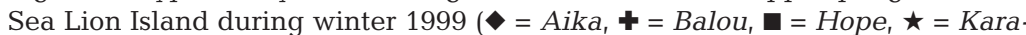
jan, $\bullet$ Leonardo and $\mathbf{\Lambda}=$ Summer). Consecutive positions separated by more than 1 duty cycle are connected by a dotted line. For further explanations see Fig. 1 


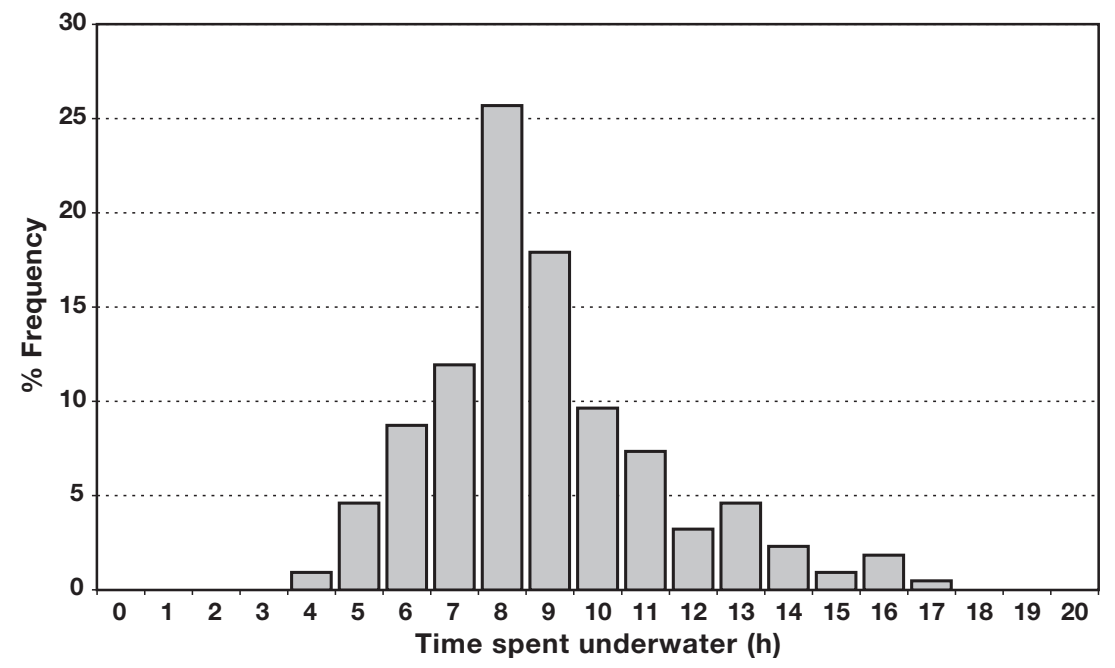

Fig. 3. Eudyptes chrysocome. Frequency distribution of the daily amounts of time spent underwater by 5 rockhopper penguins from Sea Lion Island in winter 1999

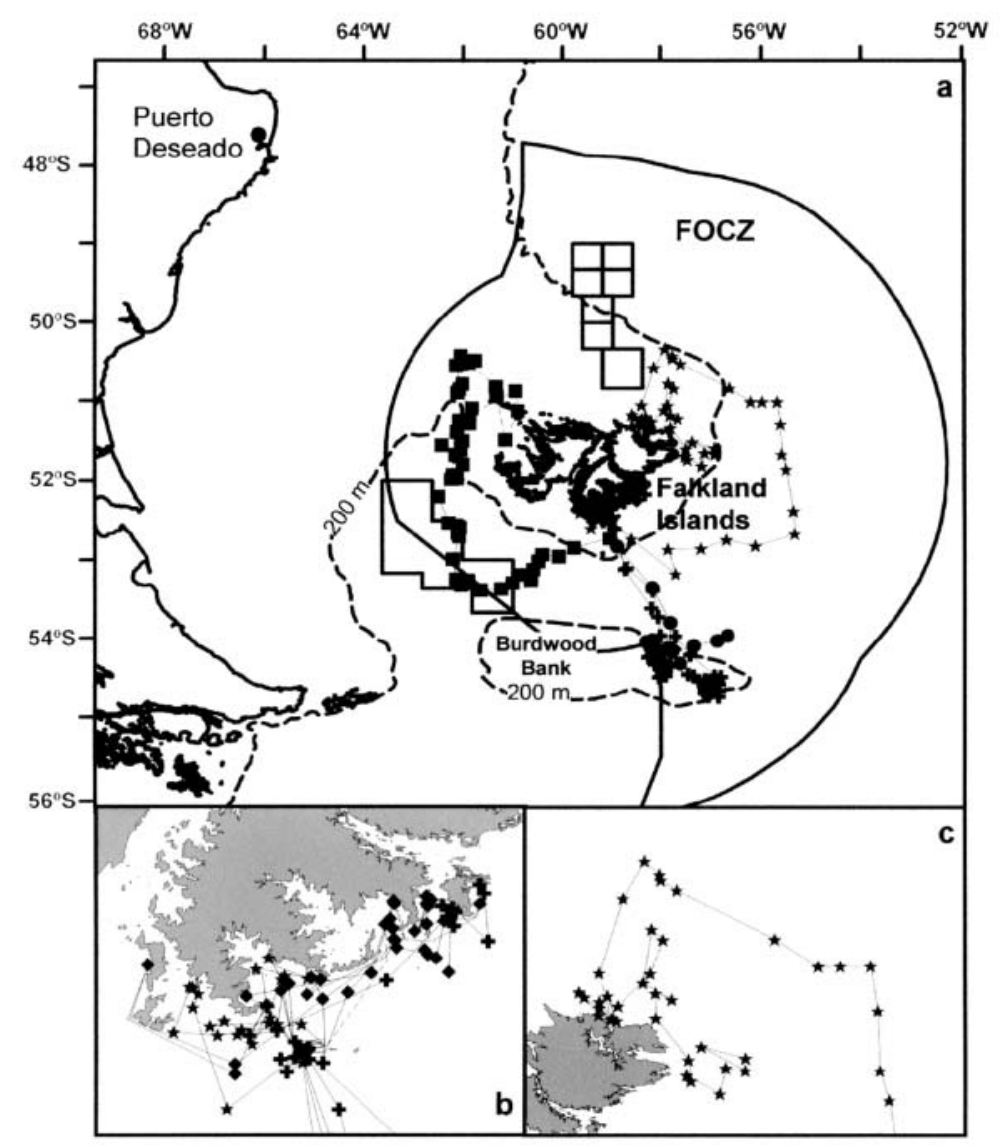

Fig. 4. Eudyptes chrysocome. Migration routes of rockhopper penguins from Sea Lion Island during winter $2000(\boldsymbol{\square}=$ Benno, $\bullet=$ Max,$+=$ Petra,$\star=$ Stella and $\bullet=$ Vreni). Consecutive positions separated by more than 1 duty cycle are connected by a dotted line. For further explanations see Fig. 1. (a) Overview, (b,c) coastal details within 1 wk after being fitted with transmitters and were subsequently monitored for a mean duration of $62 \pm 25 \mathrm{~d}$ (Fig. 4). During that time, all of the penguins stayed within the FOCZ or adjacent waters and never travelled further than $300 \mathrm{~km}$ from their colony. Of the 6 penguins, 2 individuals migrated about $250 \mathrm{~km}$ south and remained close to Burdwood Bank, 2 individuals travelled to the northern coast of the Falkland Islands, and 2 penguins stayed in inshore waters off the SE coast until transmission ceased.

\section{Saunders Island}

In 2000, migrations of the rockhopper penguins from the colony on Saunders Island were investigated for the first time; contact was maintained for a mean period of $80 \pm 9 \mathrm{~d}$ (Table 1). All of the penguins left the FOCZ westwards during the study period (Fig. 5): 2 individuals travelled to the area southeast of Puerto Deseado, Argentina, and 3 penguins migrated northwards. The northernmost point reached by one bird was at about $39^{\circ} \mathrm{S}$, $1350 \mathrm{~km}$ from the breeding site (Table 1).

\section{Comparison of the foraging trips}

Rockhopper penguins migrated various distances from their moulting site, depending on the location of their winter foraging area (Fig. 6). Apart from those penguins that stayed in coastal waters of the Falkland Islands, the shortest distance between a foraging area and the breeding colony was covered by penguins from Sea Lion Island travelling $200 \mathrm{~km}$ southwards to Burdwood Bank. Other penguins travelled more than $500 \mathrm{~km}$ westwards to the coast of South America. The greatest distances from the colony, nearly $1500 \mathrm{~km}$, were covered by rockhopper penguins from the northern colonies travelling directly or via the South American coast to the north.

Some spatial and temporal differences between the foraging trips were established by statistical comparison of selected foraging parameters (Table 2). Significant inter-annual differences (Mann-Whitney $U$-test, $\mathrm{p}<0.01$ ) occurred in residence time in the colony after being fitted with the transmitter, maximum distance from the colony during the period monitored, and minimum dis- 


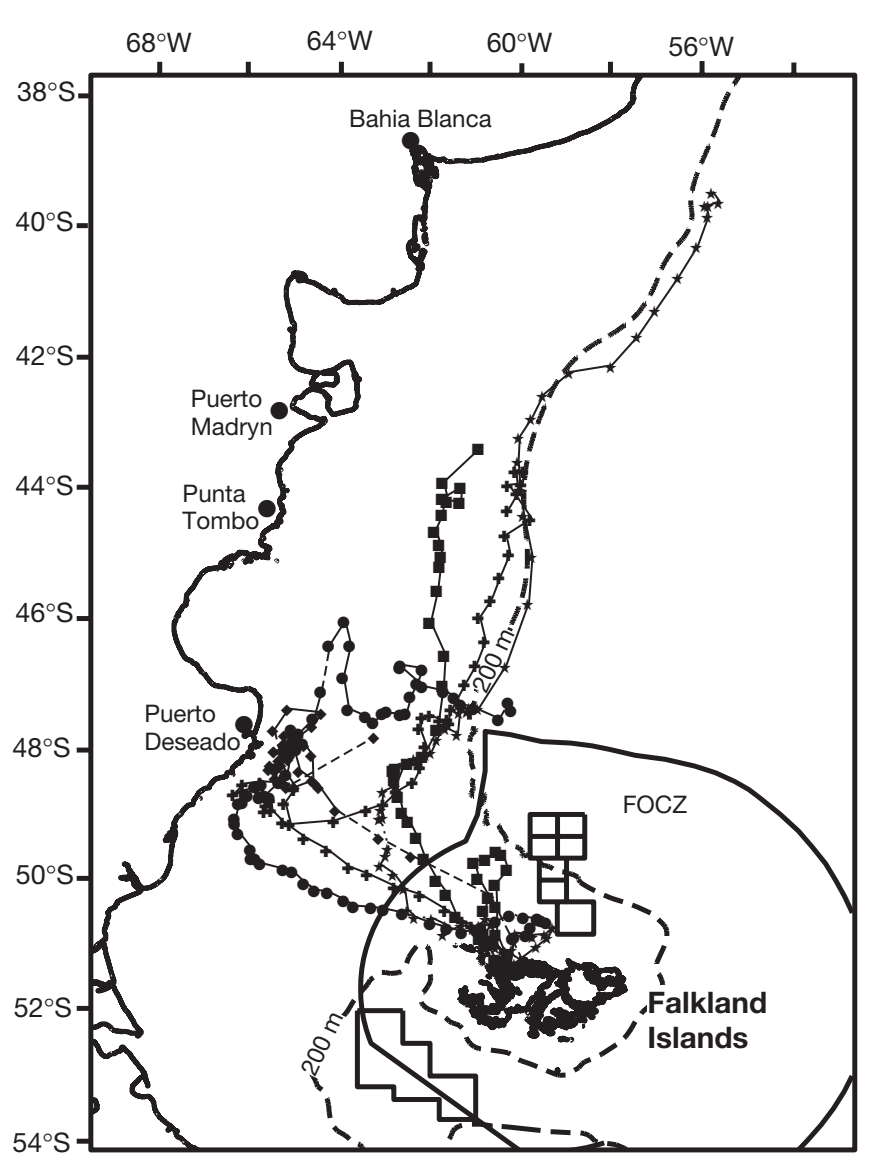

Fig. 5. Eudyptes chrysocome. Migration routes of rockhopper penguins from Saunders Island during winter $2000(\bullet=B e n j i$, $\mathbf{\square}=$ Cyrus $_{\mathbf{1}} \boldsymbol{+}=$ Inca, $\boldsymbol{\bullet}=$ Mapa and $\star=$ Millie). Consecutive positions separated by more than 1 duty cycle are connected by a dotted line. For further explanations see Fig. 1 tances covered per day in birds from Sea Lion Island in 1999 and 2000 (Table 2). Spatial differences were apparent in 2000 between rockhopper penguins from Sea Lion Island and Saunders Island with respect to maximum distance to the colony and distance covered per day, and between birds from Sea Lion Island and Seal Bay with regard to residence time in the colony after being equipped with a satellite transmitter. The lack of further significant differences in the foraging patterns of rockhopper penguins from the Falkland Islands is probably due to the small sample size per colony and year. For example, in some instances p-values between 0.05 and 0.1 were noted (see Table 2).

\section{DISCUSSION}

The winter dispersal of rockhopper penguins breeding on the Falkland Islands has been studied by the use of satellite telemetry for the first time. The amount of data collected over 3 yr makes this study the most comprehensive ever performed with satellite transmitters on any seabird species outside the breeding season. Results not only highlighted the importance of the Patagonian Shelf as a wintering area for rockhopper penguins, but also revealed significant inter-annual and spatial differences in their migration patterns. This, in turn, has major implications for the validity of conclusions drawn from the majority of satellite telemetric studies, which were performed at one locality and during one season only. However, in an attempt to verify whether the winter movements of these birds were typical, it seems appropriate to evaluate first any potentially detrimental effects of the devices on the penguins studied.

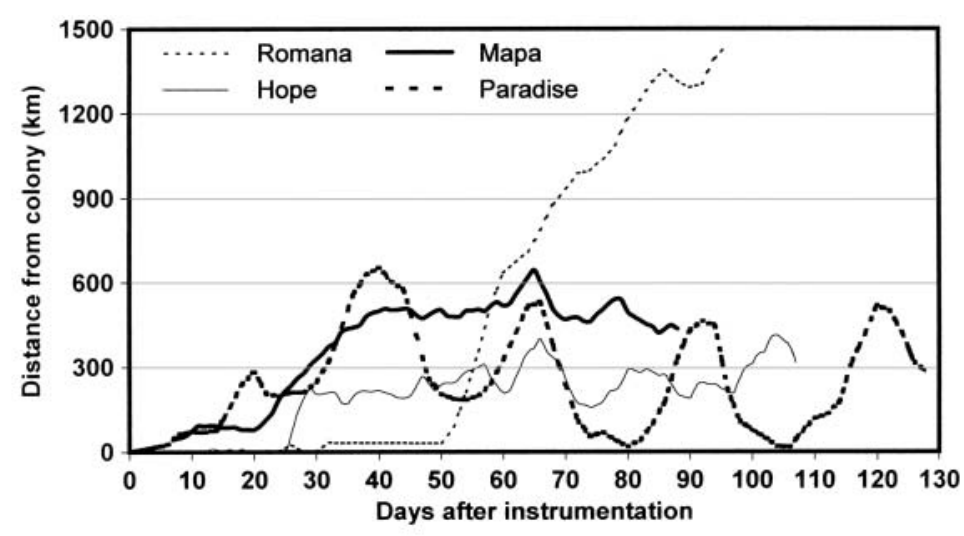

Fig. 6 Eudyptes chrysocome. Maximum range of selected rockhopper penguins from the Falkland Islands satellite-tracked during the initial part of their winter migration: Romana (Seal Bay 1998) migrated northwards, Mapa (Saunders Island 2000) migrated westwards, Hope (Sea Lion Island 1999) migrated southwards, and Paradise (Seal Bay 1998) commuted between Falkland Islands waters and foraging areas to the west

\section{Potential impact of the satellite transmitters on the behaviour of the penguins}

The attachment of devices to free-ranging animals may influence their foraging behaviour (e.g. Bannasch 1995, Ropert-Coudert et al. 2000). Externally attached units increase the penguins' hydrodynamic resistance (Bannasch et al. 1994), increasing energy expenditure and/or reducing swimming speed (Culik \& Wilson 1991). This effect is even more pronounced with satellite transmitters, as the antenna adds substantially to the drag of the backpack. Measures were taken to minimise impacts in this study. The penguins were not marked individually with the commonly used flipper bands, because these may have detrimental effects themselves (cf. Jackson \& Wilson 2002) that are likely to add to any 
Table 2. Eudyptes chrysocome. Mann-Whitney $U$-test of spatial and inter-annual differences in foraging parameters of Falkland Island rockhopper penguins equipped with satellite transmitters over the winter period. Significant $p$-values $(p<0.05)$ are shown in bold, p-values in italics are $<0.1$

\begin{tabular}{|lccc|}
\hline $\begin{array}{l}\text { Comparison between colonies } \\
\text { and year of study }\end{array}$ & $\begin{array}{c}\text { Residence time in colony } \\
(\mathrm{d})\end{array}$ & $\begin{array}{c}\text { Max. distance to the colony } \\
(\mathrm{km})\end{array}$ & $\begin{array}{c}\text { Min. distance covered } \\
\left(\mathrm{km} \mathrm{d}^{-1}\right)\end{array}$ \\
\hline Seal Bay '99 - Sea Lion Island '99 & 0.7 & 0.82 & 0.24 \\
Seal Bay '00 - Sea Lion Island '00 & 0.48 & 0.052 & 0.25 \\
Seal Bay '00 - Saunders Island '00 & $\mathbf{0 . 0 0 9}$ & 0.93 & 0.082 \\
Sea Lion Island '00 - Saunders Island '00 & 0.052 & $\mathbf{0 . 0 0 8}$ & $\mathbf{0 . 0 0 8}$ \\
Seal Bay '98 -Seal Bay '99 & 0.43 & 0.93 & 0.43 \\
Seal Bay '98 - Seal Bay '00 & 0.54 & 0.33 & 0.79 \\
Seal Bay '99 - Seal Bay '00 & 0.31 & 0.82 & 0.48 \\
Sea Lion Island '99 - Sea Lion Island '00 & $\mathbf{0 . 0 0 2}$ & $\mathbf{0 . 0 0 7}$ & $\mathbf{0 . 0 0 4}$ \\
\hline
\end{tabular}

potential disturbance to the birds caused by the satellite transmitters.

It is generally impossible to assess precisely the potential impact of externally attached devices without establishing a control group (but see Ropert-Coudert et al. 2000). Therefore, only indirect measures may indicate potential impacts, such as, for example, energetic studies (e.g. using doubly labeled water) or time budgets. Also, measurement of survival, physical condition or reproduction rates may give some indication of potential effects of the devices. However, in longterm studies on non-breeding animals that are unlikely to be recaptured, these measures are not applicable. The assessment of any potential disturbance caused by the devices is therefore extremely difficult.

In our study, clues about potential effects of the devices on the birds' behaviour can only be derived from the transmitting times, which ranged between 23 and $129 \mathrm{~d}$. Nearly $50 \%(\mathrm{n}=15)$ of transmission failures occurred after 80 to $100 \mathrm{~d}$, and more than $85 \%(\mathrm{n}=29)$ of all transmitters lasted between 60 and 120 d. Penguins bite and break their feathers to remove the devices attached to them (Wilson et al. 1997), which has been confirmed by the re-sighting of birds previously equipped with satellite transmitters (Kerry et al. 1995, Stokes et al. 1998, Pütz et al. 2000, this study). Due to the increased energy demands following starvation during moulting, birds should be most vulnerable to any detrimental effects at the very beginning of their winter migration. Thus, any losses linked to the devices should occur within the first few weeks after the birds are equipped. In our study, only 1 penguin was lost within the first $6 \mathrm{wk}$ after being equipped. The reason for the cessation of transmission signals is unknown and it cannot be ruled out that the transmitter contributed to the death of this individual. However, transmission from all other penguins lasted much longer, and it can therefore be assumed that the loss of contact was caused by the loss of the transmitters. This assumption is further substantiated by the fact that some consistent migration patterns were apparent in the penguins studied, irrespective of the location of their breeding colony or the study period (see next subsection). Therefore, given the urgent need to collect baseline data on the winter dispersal of penguins from the Falkland Islands to develop adequate measures for species and habitat protection, we felt it was justified to equip penguins with satellite transmitters, although the potential effects on their behaviour remains largely unknown.

\section{Winter foraging areas}

Like many other marine top predators breeding in the southern Atlantic Ocean (e.g. Croxall \& Wood 2002), rockhopper penguins make extensive use of the Patagonian Shelf waters during winter, utilising an area ranging from $38^{\circ}$ to $55^{\circ} \mathrm{S}$ and $51^{\circ}$ to $69^{\circ} \mathrm{W}$. Vast parts of this region were used mainly for travelling or commuting, and 4 major winter foraging areas for rockhopper penguins from the Falkland Islands were identified (Fig. 7): (1) inshore waters of the Falkland Islands, mainly to the north and west, (2) in the vicinity of Burdwood Bank to the south of the Falkland Islands, (3) at the slope of the Patagonian Shelf northwards beyond $40^{\circ} \mathrm{S}$, and (4) waters along the Argentine coast between 48 and $54^{\circ} \mathrm{S}$. The utilisation of these areas sometimes varied significantly (Table 2) between years and breeding colonies, maybe due to fluctuations in the food supply. The winter diet of rockhopper penguins is unknown, but presumably does not differ from that in the breeding season; during the breeding season their diet consists mainly of crustaceans, with varying proportions of fish and squid taken according to locality and season (for a review, see Williams 1995). In the Falkland Islands, rockhopper penguins feed opportunistically on a mixture of lobster krill Munida gregaria, fish and squid (Pütz et al. 2001). The Patagonian squid Loligo gahi has been found in the diet of rockhopper penguins breeding on Penguin 


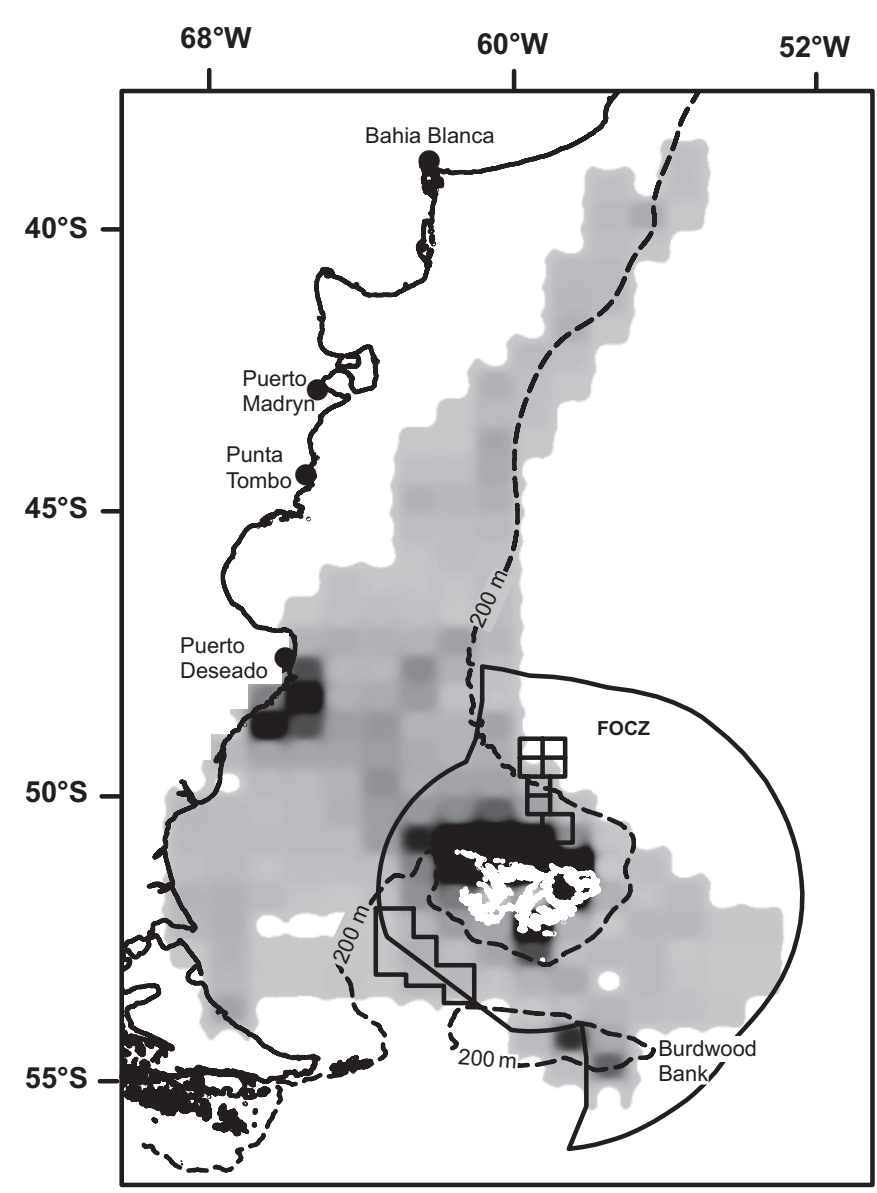

Fig. 7. Eudyptes chrysocome. Density distribution of positions received from rockhopper penguins breeding in Falkland Islands waters, satellite-tracked during the initial part of their winter migration. The level of shading is proportional to the number of positions obtained in each grid square (light grey = 1 position (total range), dark grey $\geq 17$ positions ( $1 \%$ of all positions), black $\geq 35$ positions ( $2 \%$ of all positions). The density plot was derived using the raster grid procedure in MapInfo 5.0. All raster grids were based on a resolution of $0.5^{\circ}$ latitude $\times 1^{\circ}$ longitude. In order to obtain one locational fix per day and bird, the different duty cycles were standardised by interpolating missing locational fixes in cases where the duty cycle was longer than $1 \mathrm{~d}$. This procedure was based on the assumption that birds travelled on a straight line course and at a constant speed between 2 consecutive fixes. For further explanations see Fig. 1

Island, about $50 \mathrm{~km}$ southeast of Puerto Deseado, Argentina (E. Frere \& P. Gandini pers. comm.), and this prey species appears to be abundant in the area all year round (Pineda et al. 1996).

\section{Threats from fisheries and oil drilling}

Food availability is largely influenced by the productivity of water masses transported to the main foraging areas. The major oceanographic feature influencing the waters of the Falkland Islands is the Falklands Current (Glorioso \& Flather 1995), which has its origin in the Antarctic circumpolar current and transports nutrient-rich sub-Antarctic water masses to the north. It flows in 2 branches around the Falkland Islands and then continues its northward flow along the shelf slope (Glorioso \& Flather 1995). Further to the west, along the Argentine coast, the Brazil current acts as a counter-current and transports subtropical waters from north to south. These hydrographic features create a nutrient-rich system over the Patagonian Shelf that supports the development of a rich marine life. As a consequence, these areas are heavily exploited by fisheries, posing potential threats to the rockhopper penguins and/or their prey. A fishing fleet of more than 200 vessels operates in the FOCZ, catching approximately $200000 \mathrm{t}$ of fish and squid annually (Falkland Island Government 2000). At the beginning of the 1990s exploitation was even higher, but the number of fishing licenses issued has been reduced to conserve fish and squid stocks. Approximately the same number of fishing vessels operate from harbours in Patagonia (Crespo et al. 1997), and foreign vessels also operate within the Argentine EEZ and adjacent waters.

Another potential threat to seabirds and mammals foraging over the Patagonian shelf comes from oil pollution. In the Argentine EEZ oil exploration is taking place at a number of sites, and oil exploration and production in the FOCZ are being promoted by the Falkland Islands Government (2001). Hydrocarbon exploration was conducted in 1998 the north of the Falkland Islands, and a Special Area of Co-operation (SAC) to the southwest is earmarked for future exploration. Oilrelated activities within Falkland Islands waters are currently suspended, but hydrocarbon exploration and production may start in the near future (Falkland Islands Government 2001). Both fishing and oil drilling have the potential to threaten the winter foraging areas of rockhopper penguins from the Falkland Islands or may, at least, add to limitations imposed by the fluctuating food supply.

Rockhopper penguins, as all other migratory penguin species, depart from their moulting sites very soon after completing their moult, and remain absent until the next breeding season (Williams 1995). Consistent with this, in 1998 and 2000, all birds investigated at Seal Bay and Sea Lion Island left their moulting site within 1 wk after being equipped with their transmitter, and did not return. In contrast, most penguins investigated in these 2 colonies in 1999, as well as some penguins from Saunders Island in 2000, frequently returned to their moulting/breeding site after making short foraging trips. How can this behaviour be explained? Obviously, the local food supply was suffi- 
cient to meet the rockhopper penguins' energy demands following their 1999 moult, as commercial catches of the Patagonian shortfin squid Illex argentinus in Falkland Islands waters between April and June were 3 times higher than in 1998 and twice as high as in 2000 (Falkland Islands Government 2000). A high abundance of shortfin squid was associated with a lower proportion of frontal waters, or a higher proportion of favourable waters in the range 16 to $18^{\circ} \mathrm{C}$ within the inferred hatching area in the year preceding the fishery (Waluda et al. 2001). On the other hand, favourable conditions for shortfin squid were not reflected in the catch of other commercially exploited species, as in April to June 1999 the total catch excluding $I$. argentinus was about $25 \%$ lower than in the other 2 years (Falkland Islands Government 2000). Both rockhopper penguins and $I$. argentinus feed mainly on crustaceans, namely hyperiids and euphausiids (Mouat et al. 2001), and rockhopper penguins also take small-sized shortfin-squid (Pütz et al. 2001). Conditions favouring the development of shortfin squid may thus have an effect on the food available to rockhopper penguins. Water temperatures to the northwest of the Falkland Islands waters were unusually high in 1999 compared to 1998 and 2000 (D. Middleton \& A. Arkhipkin pers. comm.), but further research is needed to gain more insight into the interactions between oceanographic conditions and food availability for top predators in the SW Atlantic.

\section{Inshore Falkland waters}

Apart from the areas directly adjacent to the moulting/breeding colonies, the inshore area most frequented by birds from all 3 colonies was situated in shallow coastal waters to the northwest of the Falkland Islands. At-sea observations also noted locally high densities of rockhopper penguins west of the Falkland Islands (White et al. 2002). Due to the inter-annual variations in residence times of penguins in that area, prey abundance can be assumed to undergo inter-annual fluctuations. This area is neither directly affected by fishing activities (Falkland Islands Government 2000) nor by hydrocarbon exploration (Falklands Islands Government 2001). However, as this area is influenced by the western branch of the Falklands Current, any oil pollution originating from SAC to the southwest of the Falkland Islands will be transported to the western part of the Falkland Islands, with presumably detrimental consequences for all marine life in the area. This study provides baseline data which should be taken into account in the creation and maintenance of an appropriate oil spill response capability.
Burdwood Bank

The foraging area situated furthest south, Burdwood Bank and adjacent oceanic areas to the northeast, was frequented only by birds breeding at Sea Lion Island. This area is directly influenced by the Falklands current (Glorioso \& Flather 1995) and is not threatened by oil pollution, because shipping routes and oil rigs are located further north. Fishing in the area is restricted to longlining, either from vessels licensed from the Falkland Islands (Falkland Islands Government 2000) or from Argentine vessels (Crespo et al. 1997). In contrast to flying seabirds, which are in danger of becoming entangled and drowning during the setting or hauling operation of the longlines (e.g. Alexander et al. 1997), this fishing method does not pose any known threat to penguins.

\section{Northern Patagonian shelf}

The third major foraging area was situated along the slope of the Patagonian shelf to the north, where only birds from the northern colonies foraged. Fishing operations do occur in the area, but the predominant fishing method is jigging (Crespo et al. 1997). Like longlining, jigging does not pose an immediate threat to rockhopper penguins, which are occasionally caught accidentally on the jigging hooks, but usually released alive (Falkland Islands Fisheries Department unpubl. data). As mentioned earlier, rockhopper penguins and shortfin squid may compete for the same prey, which would explain the importance of this area for wintering rockhopper penguins. The immense light intensity generated by jigging vessels (Rodhouse et al. 2001) may affect seabirds in general and penguins in particular. The Patagonian shelf slope used for jigging is situated to the north of the area where hydrocarbon exploration took place in 1998 (Falkland Islands Government 2000). Any oil pollution generated in these areas will subsequently drift northwards with the Falklands Current and poses an immediate threat to seabirds foraging in that area.

\section{Puerto Deseado area}

By far the most important foraging area for wintering rockhopper penguins from the Falkland Islands was situated about $50 \mathrm{~km}$ off the coast of Argentina, between Puerto Deseado $\left(48^{\circ} \mathrm{S}\right)$ and Rio Gallegos $\left(52^{\circ} \mathrm{S}\right)$. Immediately to the north of the area is the southern border of a large fishing area where trawlers target shrimp and hake (Crespo et al. 1997). Apart from the immediate competition between penguins 
and fisheries, small numbers of penguins and other top predators may become caught accidentally in the net during fishing operations (e.g. Yorio \& Caille 1999, Gandini et al. 1999, K. Pütz pers. obs.). Oil pollution frequently occurs north of this area, killing 40000 Magellanic penguins Spheniscus magellanicus each year along the coast of the Argentine province of Chubut, a coastline of approximately $3000 \mathrm{~km}$ to the north of Puerto Deseado (Gandini et al. 1994); breeding pair numbers at some Magellanic penguin colonies have fallen recently (Williams 1995). The main cause of this oil pollution is believed to be bilge water and ballast tank cleaning, and thus may occur further south as well. Rockhopper penguins from the Falkland Islands do not use coastal waters of Chubut province in winter, but they may be exposed to the same threats.

\section{Outlook}

Adequate protection of the penguin populations in the Falkland Islands as well as along the Argentine coast can only be achieved by bilateral co-operation in research and legislation, and it is hoped that the recently improved political relations between the Falkland Islands and Argentina (Dodds \& Manóvil 2002) will assist in achieving this aim.

Acknowledgements. The Antarctic Research Trust gratefully acknowledges the generous financial support of the passengers aboard MV 'World Discoverer'. Special thanks are due to those who sponsored individual penguins, in particular L. Baxter, R. \& H. Bocksberger, V. Bretscher, U. Borsari, E. Corti, CS Bank Glarus, S. Downey \& Co., T. \& J. Dürst, P. Franke, H.-D. Golde, O. Haab, K. Hennig, N. Iber, E. Kredt, G. Krenger, V. \& M. Müller-Hemmi, M. Petermann, S. \& L. Poppen, M. Rank, M. Römer, E. Sarbach, V. Sarbach-Schütz, H.-U. Schneebeli, P. Schneuwly, E. \& H. Stettler, H. Vontobel and R. \& J. Walters. Further financial and logistical support was provided by Falklands Conservation, Falklands Conservation Penguin Appeal, the people of the Falkland Islands (radio-auction) and Strachan Visick. Thanks are due to Kate Barlow, Andrew Black, Andrea Clausen, Chris Harris and Alex Ombeck for their support during fieldwork. Special thanks to Lesley Baxter for language editing. We are particularly grateful to John Croxall, Alexander Arkhipkin and 1 anonymous referee whose valuable comments greatly improved the manuscript. Melanie and Peter Gilding, Jenny Luxton and Susan and David Pole-Evans kindly provided access to the rockhopper penguin colonies at Seal Bay, Sea Lion Island and Saunders Island, respectively. This study was approved by the Falkland Islands Government and complied with the legal requirements in the Falkland Islands.

\section{LITERATURE CITED}

Alexander K, Robertson G, Gales R (1997) The incidental mortality of albatrosses in longline fisheries. Australian Antarctic Division, Hobart
Argos (1996) User's manual. CLS service Argos, Toulouse

Bannasch R (1995) Hydrodynamics of penguins - an experimental approach. In: Dann P, Normann I, Reilly P (eds) The penguins: ecology and management. Surrey Beatty \& Sons, Melbourne, p 141-176

Bannasch R, Wilson RP, Culik BM (1994) Hydrodynamic aspects of design and attachment of a back-mounted device in penguins. J Exp Biol 194:83-96

Barton J (2002) Fisheries and fisheries management in Falkland Islands Conservation Zones. Aquat Conserv 12: $127-135$

Bennett AG (1933) The penguin population of the Falkland Islands in 1932/33. Government Press, Falkland Islands

Bingham M (1998) The distribution, abundance and population trends of gentoo, rockhopper and king penguins in the Falkland Islands. Oryx 32:223-232

BirdLife International (2000) The threatened birds of the world. Lynx Editions, Barcelona

Burger J, Gochfeld M (2002) Effect of chemicals and pollution on seabirds. In: Schreiber EA, Burger J (eds) Biology of marine birds. CRC Press, Boca Raton, FL, p 485-525

Clausen A (2001) Falkland Islands penguin census 2000/01. Falklands Conservation Report, Falklands Conservation, Stanley, Falkland Islands

Cooper J, Wolfaardt A, Crawford RJM (1997) Trends in size and success of breeding colonies of Macaroni and Rockhopper Penguins at Marion Island, 1979/80-1995/96. CCAMLR Science 4:125-147

Cooper W (1992) Rockhopper penguins at the Auckland Islands. Notornis 39:66-67

Crespo EA, Pedraza SN, Dans SL, Koen Alonso M, Reyes LM, García, Coscarella M, Schiavini ACM (1997) Direct and indirect effects of the highseas fisheries on the marine mammal populations in the northern and central Patagonian coast. J Northwest Atl Fish Sci 22:189-207

Croxall JP (1992) Southern ocean environmental change: effects on seabird, seal and whale populations. Philos Trans R Soc Lond B Biol Sci 338:339-328

Croxall JP, Wood AG (2002) The importance of the Patagonian Shelf to top predator species breeding at South Georgia. Aquat Conserv 12:101-118

Culik BM, Wilson RP (1991) Swimming energetics and performance of instrumented Adelie Penguins (Pygoscelis adeliae). J Exp Biol 158:355-368

Cunningham DM, Moors PJ (1994) The decline of Rockhopper Penguins Eudyptes chrysocome at Campbell Island, Southern Ocean and the influence of rising sea temperatures. Emu 94:27-36

Dodds KJ, Manóvil L (2002) Recent developments in relations between Argentina, Britain, and the Falkland Islands in the South Atlantic. Polar Rec 38:153-156

Ellis S, Croxall JP, Cooper J (1998) Penguin Conservation Assessment and Management Plan. IUCN/SSC Conservation Breeding Specialist Group, IUCN, Apple Valley

Falkland Island Government (2000) Fisheries Department Fisheries Statistics, Vol. 4 (1989-1999). Falkland Island Government Printing Office, Stanley, Falkland Islands

Falkland Island Government (2001) Department of Mineral Resources. August 2001 Newsletter, Stanley, Falkland Islands

Fraser WR, Trivelpiece WZ, Ainley DG, Trivelpiece SG (1992) Increases in Antarctic penguin populations: reduced competition with whales or loss of sea ice due to environmental warming? Polar Biol 11:525-531

Gandini PA, Boersma PD, Frere E, Gandini M, Holik T, Lichtschein V (1994) Magellanic penguins (Spheniscus demer- 
sus) are affected by chronic petroleum pollution along the coast of Chubut, Argentina. Auk 111:20-27

Gandini PA, Frere E, Pettovello AD, Cedrola PV (1999) Interaction between magellanic penguins and shrimp fisheries in Patagonia, Argentina. Condor 101:783-789

Glorioso PD, Flather RA (1995) A barotropic model of the currents off SE South America. J Geophys Res 100: $13427-13440$

Guinard E, Weimerskirch H, Jouventin P (1998) Population changes of the Northern Rockhopper Penguin on Amsterdam and Saint Paul Islands. Colon Waterbirds 21: $222-228$

Hull CL (1996) Morphometric indices for sexing adult Royal Eudyptes schlegeli and Rockhopper E. chrysocome Penguins at Macquarie Island. Mar Ornithol 24:23-27

Ingham RJ, Summers D (2002) Falkland Islands Cruise Ship Tourism: an overview of the 1999-2000 season and the way forward. Aquat Conserv 12:145-152

Jackson S, Wilson RP (2002) The potential costs of flipperbands to penguins. Funct Ecol 16:141-148

Kerry KR, Clarke JR, Else GD (1995) The foraging range of Adelie Penguins at Bechervaise Island, MacRobertson Land, Antarctica as determined by satellite telemetry. In: Dann P, Normann I, Reilly P (eds) The penguins: ecology and management. Surrey Beatty \& Sons, Melbourne, p 216-243

Keymer IF, Malcolm HM, Hunt A, Horsley DT (2001) Health evaluation of penguins (Sphenisciformes) following mortality in the Falklands (South Atlantic). Dis Aquat Org 45: 159-169

Montevecchi WA (2002) Interactions between fisheries and seabirds. In: Schreiber EA, Burger J (eds) Biology of marine birds. CRC Press, Boca Raton, FL, p 527-557

Moors PJ (1986) Decline in numbers of Rockhopper Penguins at Campbell Island. Polar Rec 23:69-73

Mouat B, Collins MA, Pompert J (2001) Patterns in the diet of Illex argentinus (Cephalopoda: Ommastrephidae) from the Falkland Islands jigging fishery. Fish Res (Amst) 52: $41-49$

Patterson KR (1987) Fishy events in the Falklands. New Sci 1562:44-48

Pineda SE, Aubone A, Brunetti NE (1996) Identification y morfometria comparada de las mandibulas de Loligo gahi y Loligo sanpaulensis (Cephalopoda, Loliginidae) del

Editorial responsibility: Otto Kinne (Editor),

Oldendorf/Luhe, Germany
Atlantico Sudoccidental. Rev Investig Desarro Pesq 10: 85-89

Pütz K, Ingham RJ, Smith JG (2000) Satellite tracking of the winter migration of Magellanic Penguins (Spheniscus magellanicus) breeding in the Falkland Islands. Ibis 142: $614-622$

Pütz K, Ingham RJ, Smith JG, Croxall JP (2001) Population trends, breeding success and diet composition of gentoo Pygoscelis papua, magellanic Spheniscus magellanicus and rockhopper Eudyptes chrysocome penguins in the Falkland Islands. Polar Biol 24:793-807

Richards P (2002) Overview of petroleum geology, oil exploration and associated environmental protection around the Falkland Islands. Aquat Conserv 12:7-14

Rodhouse PG, Elvidge CD, Trathan PN (2001) Remote sensing of the global light-fishing fleet: an analysis of interactions with oceanography, other fisheries and predators. Adv Mar Biol 39:262-303

Ropert-Coudert Y, Bost CA, Handrich Y, Bevan RM, Butler PJ, Woakes AJ, Le Maho Y (2000) Impact of externally attached loggers on the diving behaviour of the King Penguin. Physiol Biochem Zool 73:438-445

Schiavini ACM (2000) Staten Island, Tierra del Fuego: the largest breeding ground for Southern Rockhopper Penguins? Waterbirds 23:286-291

Stokes DL, Boersma PD, Davis LD (1998) Satellite tracking of Magellanic Penguins migration. Condor 100:376-381

Waluda CM, Rodhouse PG, Podestá GP, Trathan PN, Pierce GJ (2001) Surface oceanography of the inferred hatching grounds of Illex argentinus (Cephalopoda: Ommastrephidae) and influences on recruitment variability. Mar Biol 139:671-679

White RW, Gillon KW, Black AD, Reid JB (2002) The distribution of seabirds and marine mammals in Falkland Islands waters. Joint Nature Conservation Committee, Peterborough

Williams TD (1995) The penguins. Oxford University Press, Oxford

Wilson RP, Pütz K, Peters G, Culik B, Scolaro JA, Charrassin JB, Ropert-Coudert Y (1997) Long-term attachment of transmitting and recording devices to penguins and other seabirds. Wildlife Soc Bull 25:101-106

Yorio P, Caille G (1999) Seabird interactions with coastal fisheries in northern Patagonia: use of discards and incidental captures in nets. Waterbirds 22:207-216

Submitted: January 22, 2002; Accepted: May 24, 2002

Proofs received from author(s): August 16, 2002 